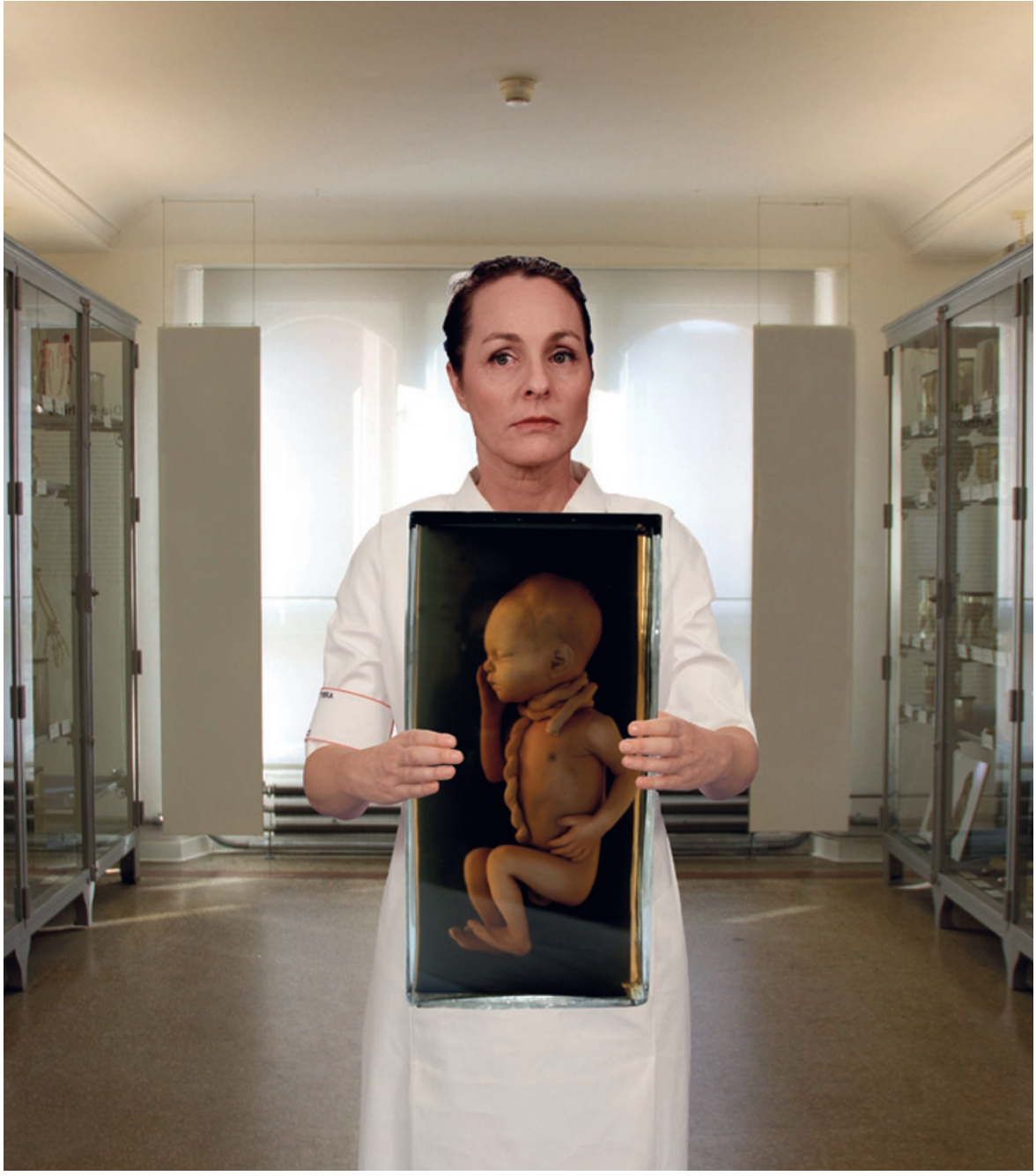

In The Cord, Aya Ben Ron reimagines the history of a baby accidentally strangled during birth.

PATHOLOGY

\section{The dead reborn}

\section{Artworks confronting the ethical dimensions of pathology specimens intrigue Alison Abbott.}

$\mathrm{I}$ f you are drawn to disembodied human organs floating in formalin, the Berlin Museum of Medical History at the Charité university hospital is just the place to visit. But behind the cases is a multifaceted political and scientific history. Into that steps Israeli artist Aya Ben Ron, whose show $A$ Voyage to Cythera has created an 'intervention' - a quiet imposition of her own way of seeing - among the pathology specimens.

There are some 750 of these on permanent display - a fraction of the tens of thousands put together by pioneering pathologist Rudolf Virchow (1821-1902) and his successors. Virchow called the collection his 'dear child' and died long before it was decimated by Second World War bombs. After the war, the museum found itself in communist East Germany, next to the Berlin Wall, with its upper west-facing windows painted black. The reunification in 1990 then saw specimens reorganized according to modern aesthetic tastes and scientific standards, aiming for dignity and didactic power.

Ben Ron's artworks - sculpture, video, sound and poetry - 'intervene' at 18 stations in a viewing trail (http://avoyagetocythera. com). Appearing dressed as a nurse in the videos, the artist presents the specimens from the viewpoint of a carer. For her, they cannot be Virchow's dear child. Nor, without the dimension of emotion, can they be truthful teaching aids: each was once part of a person. The names of these people may be long forgotten, but Ben Ron has invented new histories for them.

A Voyage to

Cythera

The Berlin Museum of Medical History. Until 9 September 2012.

The title of the exhibition is taken from the 1857 poem by Charles Baudelaire, in which the protagonist, in search of the goddess Venus, travels to the Greek island of Cythera, her birthplace. Instead of finding the goddess of love, he discovers, hanging from a tree, a rotting carcass - which turns out to be his own.

At its most basic level, this thoughtful body of works reflects, like Baudelaire's poem, on the natural yearning for love and beauty, and the reality of life - which, at the end of the day, can offer only the opposite. Ben Ron laser-cuts her sculptures (of bandaged figures or anatomy classes) from mild steel, so they begin to rust slowly from the moment of their creation.

Two of the videos focus on specimens that Ben Ron selected for their particular pathos; she invents their history in poems. One is a vast distended colon from a person who died, essentially, of constipation. Ben Ron dignifies the illness through a metaphorically rich poem. As nurse, she cradles the monstrosity protectively, and with tenderness.

The other is a perfectly developed baby, tragically strangled by its umbilical cord during birth. Both the images and poem are heart-wrenching, yet also somehow heartwarming: the child is, Ben Ron writes, "if not alive, at least in a jar".

In a room housing cardiovascular specimens, she presents a recording of a heartbeat. It sounds infrequently: a low, doom-ridden boom providing a visceral reminder to visitors that the hearts they gawp at were once alive. The sound of summer meadows plays low in the background of a room containing other organs. The birdsong lifts the spirits until the sudden, brutal buzz of a bluebottle - which lays its eggs on decaying flesh flips the mood.

One station is adjacent to a west-facing window. No longer blacked out, its clear glass looks out onto Berlin's new central station with its networks of tracks reaching across Europe. Germany's reach was not always benign; Ben Ron was influenced by her grandmother, a gynaecologist and Holocaust survivor. One of the museum's rooms is dedicated to detailing the abuses of medicine under the Third Reich. Ben Ron has a station there: a poster that hijacks the name of a 1941 propaganda film legitimizing the murder of the disabled or incurable: 'I accuse.'

Alison Abbott is Nature's Senior European Correspondent. 